\title{
Benzo(a)pyrene promotes Hep-G2 cell migration and invasion by upregulating phosphorylated extracellular signal-regulated kinase expression
}

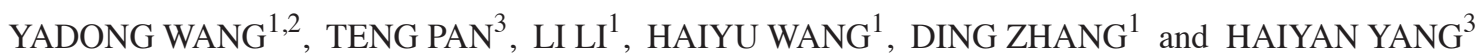 \\ ${ }^{1}$ Department of Toxicology, Henan Center for Disease Control and Prevention, Zhengzhou, \\ Henan 450016; ${ }^{2}$ Henan Collaborative Innovation Center of Molecular Diagnosis and Laboratory Medicine, \\ Xinxiang Medical University, Xinxiang, Henan 453003; ${ }^{3}$ Department of Epidemiology, School of Public Health, \\ Zhengzhou University, Zhengzhou, Henan 450001, P.R. China
}

Received August 13, 2017; Accepted March 7, 2018

DOI: $10.3892 / \mathrm{ol} .2018 .8379$

\begin{abstract}
Benzo(a)pyrene (BaP), a carcinogenic component of cigarette smoke, has been reported to activate extracellular signal-regulated kinase (ERK) in cancer cells. Furthermore, activated ERK is associated with liver cancer cell invasion and metastasis. Therefore, the aim of the present study was to investigate the potential role of phosphorylated (p)-ERK in BaP-induced Hep-G2 cell migration and invasion. An MTT assay was used to determine the effects of $\mathrm{BaP}$ treatment on Hep-G2 cell proliferation. Wound-healing and Transwell invasion assays were employed to assess the migration and invasion abilities of Hep-G2 cells. Western blot analysis was applied to detect the expression of proteins. The results of the present study demonstrated that $\mathrm{BaP}$ treatment was able to increase the level of $\mathrm{p}$-ERK protein expression in Hep-G2 cells. BaP treatment promoted Hep-G2 cell migration and invasion. The ERK inhibitor, U0126, was able to block the migration and invasion abilities of Hep-G2 cells induced by BaP. The results of the present study demonstrated that BaP treatment promoted the migration and invasion of Hep-G2 cells by upregulating p-ERK expression.
\end{abstract}

\section{Introduction}

Benzo(a)pyrene ( $\mathrm{BaP})$ is a polycyclic aromatic hydrocarbon derived from incomplete combustion of organic materials (including cigarette smoke). BaP is listed as a group I carcinogen by the International Agency for Research on

Correspondence to: Dr Yadong Wang or Professor Ding Zhang, Department of Toxicology, Henan Center for Disease Control and Prevention, 105 South Nongye Road, Zhengzhou, Henan 450016, P.R. China

E-mail: wangyd76@163.com

E-mail: zhangd222@126.com

Key words: benzo(a)pyrene, Hep-G2, migration, invasion, phosphorylated extracellular signal-regulated kinase
Cancer based on the data from animal experiments and epidemiological studies (1). Numerous studies have documented the associations between $\mathrm{BaP}$ exposure and the formation of different types of cancer (2-7), including liver cancer (8-10). It has been reported that gene mutations, chromosomal aberrations and epigenetic alterations are involved in the process of BaP-induced hepato-carcinogenesis (11-15). Recently, $\mathrm{Ba}$ et al (16) reported that $\mathrm{BaP}$ exposure had effects on the metastasis of human liver cancer cell, but the underlying mechanisms of this are not well understood.

Extracellular regulated protein kinase (ERK), a pivotal regulator of the mitogen-activated protein kinase (MAPK)/ERK pathway, has been implicated in the regulation of cell proliferation, differentiation and survival $(17,18)$. The ERK cascade reaction may be activated by various stimuli, including receptor tyrosine and G-protein-coupled receptors (19), and activated ERK may phosphorylate various downstream molecules (20). An increasing volume of evidence has demonstrated that the activated ERK signaling pathway is associated with the development and progression of liver cancer (21-25). For example, Jiang et al (26) reported that calcium binding protein 39 promoted the metastasis of liver cancer by activating the ERK signaling pathway. Dang et al (27) reported that loss of protocadherin-17 promoted the metastasis and invasion of liver cancer through hyperactivation of the epidermal growth factor receptor (EGFR)/ERK signaling pathway.

Based on the observations of previous studies that phosphorylated (p)-ERK served an important role in hepatocarcinoma cell migration and invasion, and that BaP promoted hepatocarcinoma cell migration and invasion, we hypothesized that ERK activation may serve a pivotal role in BaP-induced migration and invasion of hepatoma cells. In the present study, the most commonly studied cell line of human hepatoblastoma, Hep-G2 (28) was used to investigate the potential role of p-ERK in the BaP-induced migration and invasion of hepatoma cells.

\section{Materials and methods}

Cell culture and BaP treatment. The human hepatoblastoma Hep-G2 cell line was purchased from the Cell 
Resource Center, Peking Union Medical College (National Infrastructure of Cell Line Resource, Beijing, China). Hep-G2 cells were cultured in Dulbecco's modified Eagle's medium (DMEM) (GE Healthcare Bio-Sciences, Pittsburgh, PA, USA) supplemented with $10 \%$ fetal bovine serum (FBS) (GE Healthcare Bio-Sciences) and antibiotics (penicillin $100 \mathrm{U} / \mathrm{ml}$ and streptomycin $100 \mu \mathrm{g} / \mathrm{ml}$ ) in an incubator with a humidified atmosphere of $5 \% \mathrm{CO}_{2}$ at $37^{\circ} \mathrm{C}$. For BaP exposure, Hep-G2 cells were treated with different concentrations $(0,2,4,8,16$, 32 or $64 \mu \mathrm{M}$ ) of BaP (B1760; >96\% HPLC; Sigma-Aldrich; Merck KGaA, Darmstadt, Germany) at different time points $(0,24,48$ or $72 \mathrm{~h})$, as described previously $(29,30)$. The final concentration of dimethyl sulfoxide (DMSO) used as solvent control was $0.1 \%(\mathrm{v} / \mathrm{v})$ or less.

Cell proliferation assay. To observe the effects of $\mathrm{BaP}$ on Hep-G2 cell proliferation, an MTT assay was performed as described previously (30). In brief, $1 \times 10^{4}$ cells in $100 \mu \mathrm{l}$ DMEM (GE Healthcare Bio-Sciences) were plated into each well of 96-well plates (6 wells per group). A total of $24 \mathrm{~h}$ after plating, cells were exposed to different concentrations of $\operatorname{BaP}(0,2,4,8$, 16,32 or $64 \mu \mathrm{M}$ ) for $0,24,48$ or $72 \mathrm{~h}$. A total of $10 \mu \mathrm{l}$ of $5 \mathrm{mg} / \mathrm{ml}$ MTT was added to each well, and then the plates were incubated at $37^{\circ} \mathrm{C}$ for $4 \mathrm{~h}$. Finally, $150 \mu \mathrm{l}$ DMSO was added to each well to dissolve the purple formazan. The optical density was read on a micro-plate reader (Multiskan Ascent Software, Thermo Fisher Scientific, Inc., Waltham, MA, USA) at $492 \mathrm{~nm}$. Relative cell proliferation rates were determined by normalizing with that of the solvent control at $0 \mathrm{~h}$.

Wound healing assay. A Wound-healing assay was conducted to evaluate the migratory ability of Hep-G2 cells in accordance with our previous study (30). In brief, cells were seeded onto 6-well plates and were wounded by scratching the surface of plates with a sterile $200-\mu 1$-pipette tip. Floating cells were removed by washing with phosphate-buffered saline (PBS) three times. A total of $2 \mathrm{ml}$ DMEM (GE Healthcare Bio-Sciences) with $4 \mu \mathrm{M} \mathrm{BaP}$ or $20 \mu \mathrm{M}$ ERK inhibitor, U0126 (U120-1MG; $\geq 98 \%$ HPLC; Sigma-Aldrich; Merck KGaA), was added to each well. Images of the process of cell migration into the wound were captured using an inverted microscope (magnification, x10 and x20) equipped with a camera (Leica Microsystems GmbH, Wetzlar, Germany). The healing width was calculated as the wound width at $0 \mathrm{~h}$ minus wound width at $48 \mathrm{~h}$, and was normalized to the control.

Invasion assay. A Matrigel invasion assay was performed using a 24-well Transwell chamber (Corning Incorporated, Corning, NY, USA). A total of $5 \times 10^{4}$ cells in DMEM (GE Healthcare Bio-Sciences) without FBS were seeded into the upper chamber with Matrigel. A total of $4 \mu \mathrm{M} \mathrm{BaP}$ or $20 \mu \mathrm{M}$ U0126 were added to the upper chamber. A total of $600 \mu \mathrm{l}$ DMEM supplemented with 10\% FBS (both GE Healthcare Bio-Sciences) were added to the lower chamber. After $24 \mathrm{~h}$ of incubation at $37^{\circ} \mathrm{C}$, non-migrated cells on the upper side of the membrane were removed with cotton swabs. Cells on the lower surface of the membrane were fixed with pure methanol at room temperature for $10 \mathrm{~min}$ and stained with crystal violet at room temperature for $30 \mathrm{~min}$. The number of invaded cells was counted in six randomly selected fields.
Relative ability of invasion was calculated by normalizing with control.

Western blot analysis. Western blot analysis was performed as previously described (30). In brief, cells were harvested and washed with ice-cold PBS three times. Whole-cell lysates were prepared in radioimmunoprecipitation assay buffer with protease inhibitors and phosphatase inhibitors (Pierce; Thermo Fisher Scientific, Inc.) at $4^{\circ} \mathrm{C}$ for $15 \mathrm{~min}$, followed by $15 \mathrm{~min}$ of centrifugation $(14,000 \mathrm{x} \mathrm{g})$ at $4^{\circ} \mathrm{C}$. Total protein was determined by a bicinchoninic acid kit (Pierce; Thermo Fisher Scientific, Inc.). Equal amounts of protein $(50 \mu \mathrm{g})$ were electrophoresed on $10 \%$ sodium dodecyl sulfate polyacrylamide gel. Following electrophoresis, proteins were transferred onto nitrocellulose membranes. The membranes were washed and blocked with $5 \%$ bovine serum albumin in Tris-buffered saline and $0.1 \%$ Tween-20 at room temperature for $1 \mathrm{~h}$. The membranes were incubated with primary antibodies against the following: p-ERK1/2 (1:2,000; cat. no. 4370S), ERK1/2 (1:2,000; cat. no. 4695S), p-STAT3 (1:1,000; cat. no. 9145S), vimentin (1:1,000; cat. no. 5741S; all Cell Signaling Technology, Inc., Danvers, MA, USA), tubulin (1:1,000; cat. no. sc-365791), $\beta$-catenin $(1: 1,000$; cat. no. sc-7199), p-protein kinase B (Akt; 1:1,000; cat. no. sc-33437), MMP2 (1:1,000; cat. no. sc-10736), N-cadherin (1:1,000; cat. no. sc-7939), TGIF (1:1,000; cat. no. sc-9084), STIM1 (1:1,000; cat. no. sc-68897), Twist (1:500; cat. no. sc-81417) and E-cadherin (1:1,000; cat. no. sc-7870; all Santa Cruz Biotechnology, Inc., Dallas, TX, USA) overnight at $4^{\circ} \mathrm{C}$. The members were washed and incubated with Peroxidase-Conjugated Goat anti-Rabbit IgG (1:5,000; cat. no. ZB-2301) or Peroxidase-Conjugated Goat anti-Mouse IgG (1:5,000; cat. no. ZB-2305; all ZSGB-BIO; OriGene Technologies, Inc., Beijing, China) for $1 \mathrm{~h}$ at room temperature. The signals were captured in the ChemiDoc ${ }^{\mathrm{TM}}$ $\mathrm{XRS}^{+}$imaging system (Bio-Rad Laboratories, Inc., Hercules, MA, USA) by a Bio-Rad Clarity ${ }^{\mathrm{TM}}$ western enhanced chemiluminescence substrate (Bio-Rad Laboratories, Inc.).

Statistical analysis. Data were analyzed by one-way analysis, followed by the least significant difference test, using SPSS 13.0 software (SPSS, Inc., Chicago, IL, USA). All values are expressed as the mean \pm standard deviation (SD). $\mathrm{P}<0.05$ was considered to indicate a statistically significant difference.

\section{Results}

The effects of BaP treatment on Hep-G2 cell proliferation. The results of the present study demonstrated that Hep-G2 cell proliferation was significantly suppressed by 16,32 and $64 \mu \mathrm{M} \mathrm{BaP}$ treatment at 48 and $72 \mathrm{~h}$, compared with the solvent control (Fig. 1). When the concentration of BaP treatment was $<8 \mu \mathrm{M}$, the cell proliferation was not significantly affected (Fig. 1). Therefore, the highest dose of BaP treatment did not exceed $8 \mu \mathrm{M}$ for the subsequent experiments, as it had no obvious toxicity to cells at this concentration.

The effects of BaP treatment on the expression of p-ERK. The results of the present study demonstrated that the expression of $\mathrm{p}$-ERK protein was markedly increased in the BaP-treated 


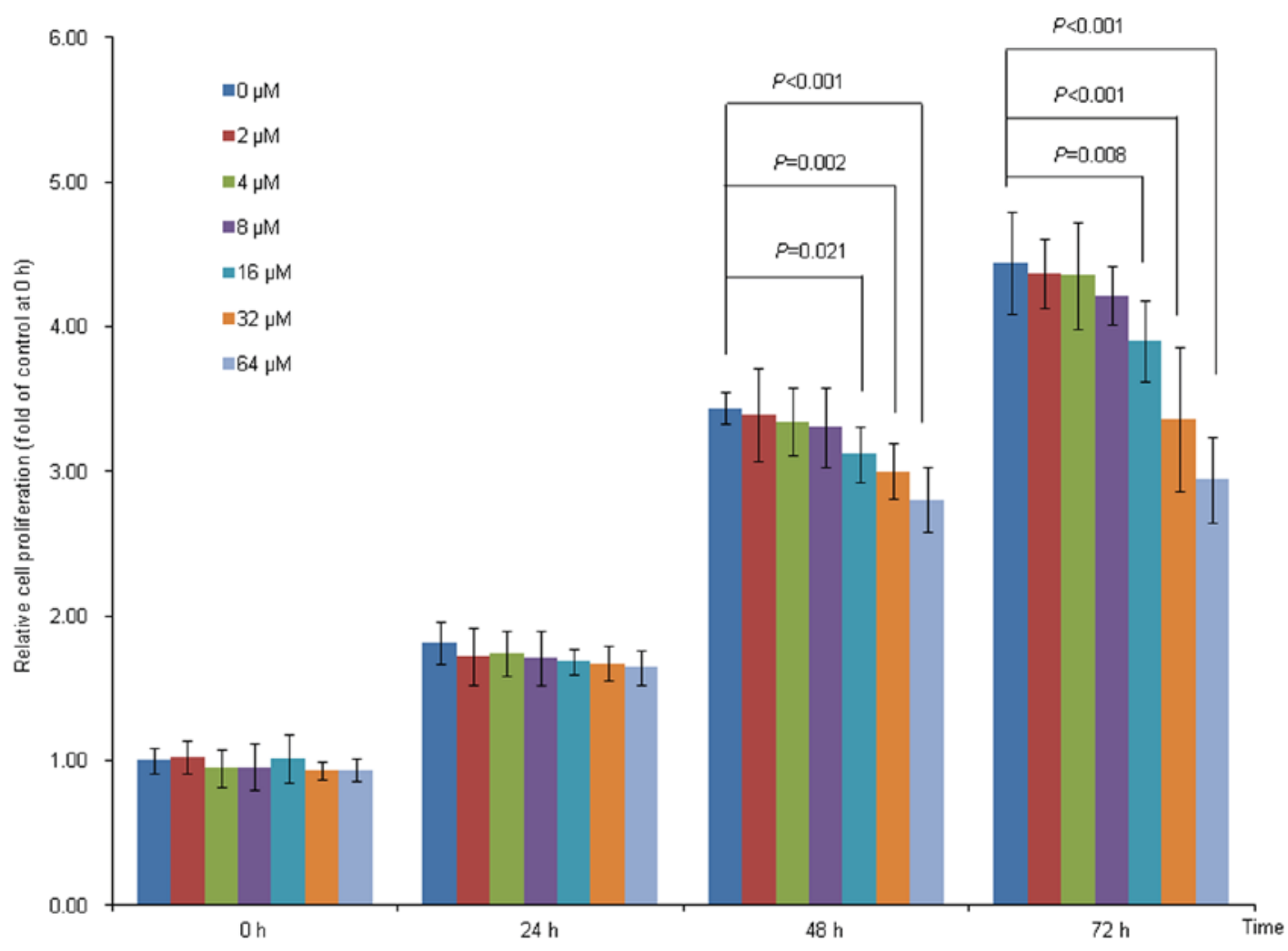

Figure 1. Effects of BaP treatment on Hep-G2 cell proliferation. Hep-G2 cells were treated with different concentrations of $\mathrm{BaP}(0,2,4,8,16,32$ or $64 \mu \mathrm{M})$ for $0,24,48$ or $72 \mathrm{~h}$, and an MTT assay was performed. Relative cell proliferation rates were determined by normalizing with that of the solvent control at $0 \mathrm{~h}$. Data are expressed as the mean \pm standard deviation. BaP, benzo(a)pyrene.

groups $(2,4$ and $8 \mu \mathrm{M})$, compared with the solvent control group (Fig. 2). Furthermore, BaP exposure $(8 \mu \mathrm{M})$ markedly increased the expression of p-ERK protein at 24,48 and $72 \mathrm{~h}$, compared with the solvent control (Fig. 2). BaP treatment had no obvious effects of total ERK expression, and tubulin was used as loading control.

The effects of BaP treatment on Hep-G2 cell migration and invasion. Fig. 3 demonstrated the effects of $\mathrm{BaP}$ treatment on Hep-G2 cell migration and invasion in vitro. The results demonstrated that Hep-G2 cells treated with $\mathrm{BaP}(2$ and $4 \mu \mathrm{M})$ migrated more quickly to heal the scratched wounds than the cells treated with DMSO (Fig. 3A and B). Furthermore, the results of the present study indicated that Hep-G2 cells treated with $\mathrm{BaP}$ ( 2 and $4 \mu \mathrm{M})$ had an enhanced ability to invade through the Matrigel matrix, compared with cells treated with DMSO (Fig. 3C and D).

Increased ERK activity is required for BaP-induced Hep-G2 cell migration and invasion. As described earlier, BaP treatment induced the expression of p-ERK protein and enhanced the migration and invasion abilities of Hep-G2 cells. To further investigate whether or not ERK signaling serves an important role in the $\mathrm{BaP}$-induced migration and invasion of Hep-G2 cells, wound-healing and Transwell invasion assays were performed in the presence of $\mathrm{BaP}$ and a known ERK inhibitor, U0126. The results data demonstrated that the ERK inhibitor, U0126, significantly inhibited the migration and invasion of Hep-G2 cells. As demonstrated in Fig. 4A, the scratched wound width was markedly wider in the U0126-treated group (+) than that in the U0126-untreated group (-) at $48 \mathrm{~h}$ (Fig. 4A). When the migration ability was represented as the healing width, it was observed that the healing width was markedly decreased in U0126-treated group (+) as compared with U0126-untreated group (-) at $48 \mathrm{~h}$ (Fig. 4B). The number of invaded cells was markedly decreased in U0126-treated group (+), compared with the U0126-untreated group (-) (Fig. 4C and D). Furthermore, the results of the present study demonstrated that blocking of ERK activation abolished the abilities of the migration (Fig. 4A and B) and invasion (Fig. 4C and D) of Hep-G2 cells induced by treatment with $\mathrm{BaP}$, which suggested that Hep-G2 cell migration and invasion induced by BaP treatment may be mediated by ERK activation.

BaP-induced vimentin protein expression is modulated by ERK activation. Several proteins, including matrix metalloproteinase 2 (MMP2), p-Akt, E-cadherin, N-cadherin and vimentin serve important roles in the invasion and metastasis of liver cancer (31-34). Whether or not these proteins were involved in the downstream targets of ERK signaling in Hep-G2 cells treated with BaP was subsequently investigated. The expression of these proteins in the presence of $\mathrm{BaP}$ and the ERK inhibitor, U0126, was detected. The results demonstrated that the increased expression of vimentin protein was observed in the $\mathrm{BaP}$ treatment group, compared with the solvent control, which was inhibited by treatment with U0126 (Fig. 5). No effect on the expression 


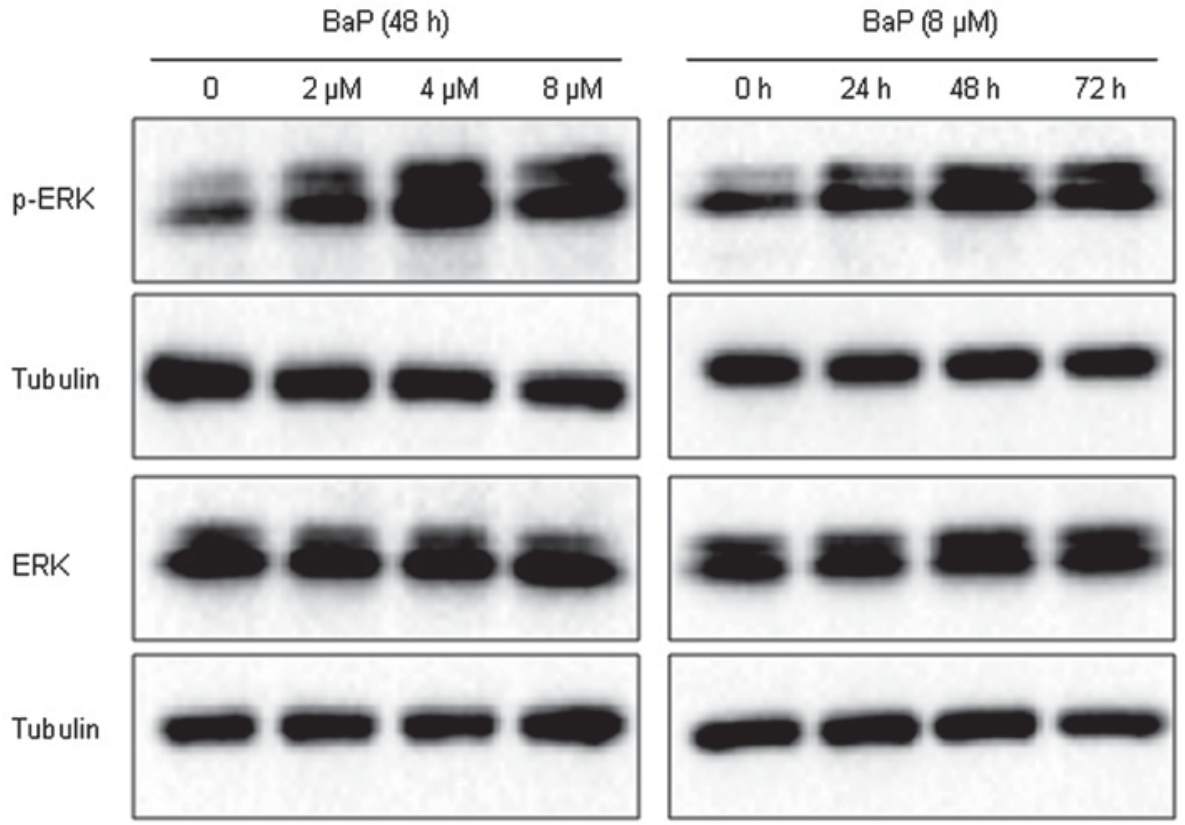

Figure 2. Effects of $\mathrm{BaP}$ treatment on the expression of p-ERK protein. Hep-G2 cells were treated with various concentrations of $\mathrm{BaP}(0,2,4$ or $8 \mu \mathrm{M})$ for $48 \mathrm{~h}$ or $8 \mu \mathrm{M}$ of $\mathrm{BaP}$ for 24,48 or $72 \mathrm{~h}$. Western blot analysis was performed to detect the expression of p-ERK protein. BaP, benzo(a)pyrene; p-ERK, phosphorylated extracellular signal-regulated kinase.

A

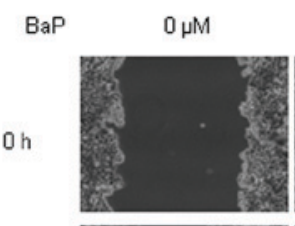

$48 \mathrm{~h}$

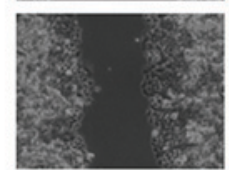

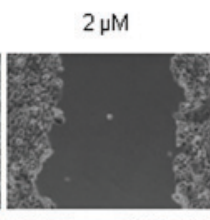

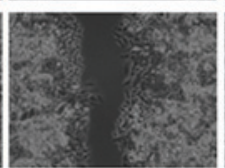

B

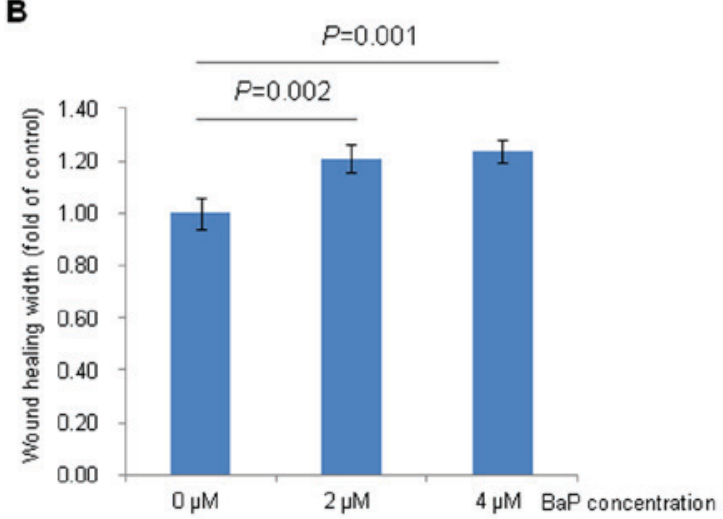

C

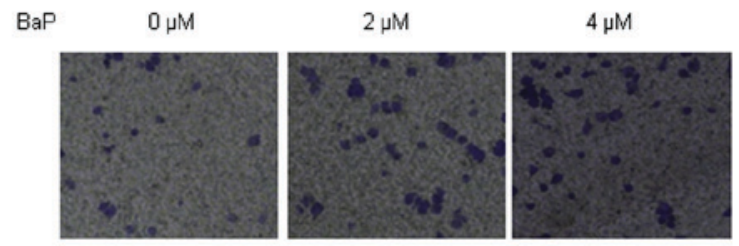

D

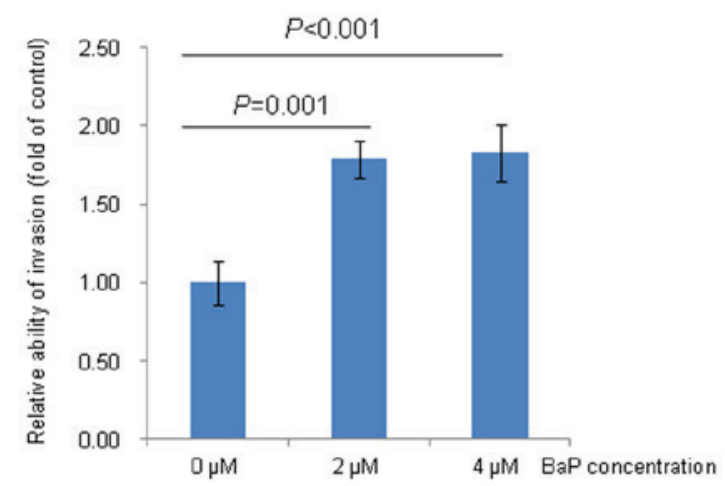

Figure 3. Effects of BaP treatment on Hep-G2 cell migration and invasion. Wound-healing assay was (A) performed and (B) quantified to evaluate the effects of $\mathrm{BaP}$ treatment on Hep-G2 cell migration. Cells were wounded by scratching and treated with $\mathrm{BaP}(0,2$, or $4 \mu \mathrm{M})$ for $48 \mathrm{~h}$. Images were captured at 0 and $48 \mathrm{~h}$. The healing width was calculated as the wound width at $0 \mathrm{~h}$ minus the wound width at $48 \mathrm{~h}$ and was normalized to the control. Values are expressed as the mean \pm standard deviation. Transwell invasion assay was (C) performed and (D) quantified to assess the effects of BaP treatment on Hep-G2 cell invasion. Cells were harvested and seeded into the upper chamber with Matrigel and treated with $\mathrm{BaP}(0,2$ or $4 \mu \mathrm{M})$ for $24 \mathrm{~h}$. The number of migrated cells was counted and normalized to the control. Values are expressed as the mean \pm standard deviation. BaP, benzo(a)pyrene.

of proteins, including $\beta$-catenin, p-Akt, MMP2, E-cadherin and $\mathrm{N}$-cadherin in Hep-G2 cells was observed followed treatment with BaP (Fig. 5). Additionally, the expression of additional proteins, including TGFB-induced factor (TGIF), 
A

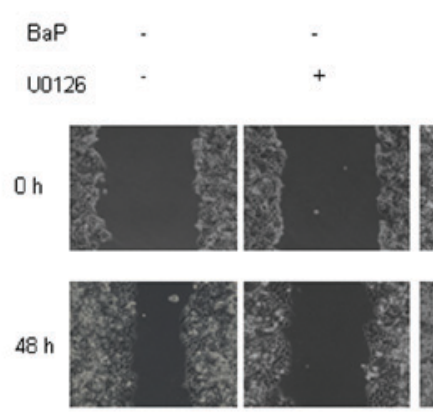

C

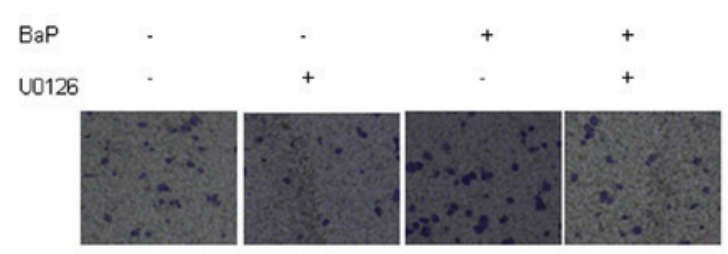

B

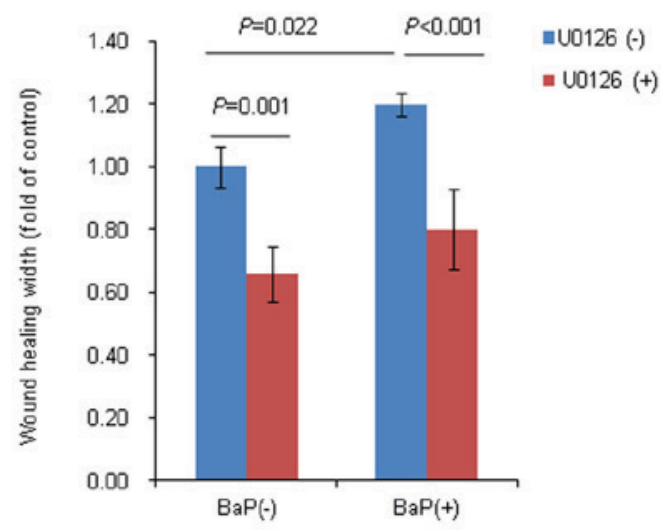

\section{D}

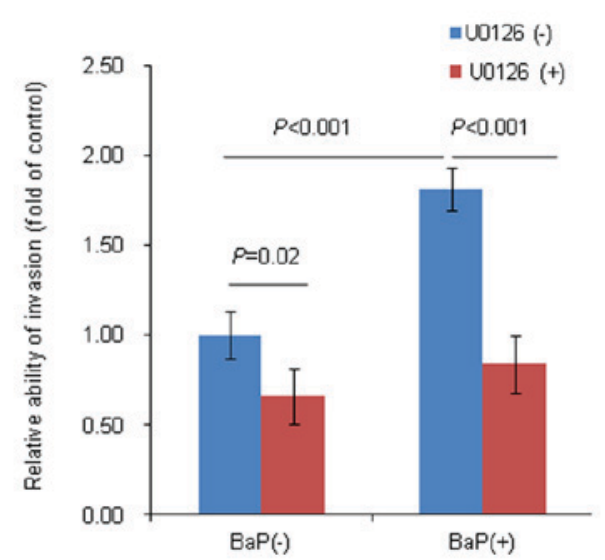

Figure 4. ERK activation is required for BaP-induced Hep-G2 cell migration and invasion. Wound-healing assay was (A) performed and (B) quantified to evaluate the potential role of p-ERK in BaP-induced Hep-G2 cell migration. Cells were wounded by scratching and cultured in the presence of BaP $(4 \mu \mathrm{M})$ or U0126 $(20 \mu \mathrm{M})$ for $48 \mathrm{~h}$. Images were captured at 0 and $48 \mathrm{~h}$. The healing width was calculated as the wound width at $0 \mathrm{~h}$ minus the wound width at $48 \mathrm{~h}$ and was normalized to the control. Values are expressed as the mean \pm standard deviation. Transwell invasion assay was (C) performed and (D) quantified to assess the potential role of p-ERK in BaP-induced Hep-G2 cell invasion. Cells were harvested and seeded into the upper chamber with Matrigel and were cultured in the presence of $\mathrm{BaP}(4 \mu \mathrm{M})$ or $\mathrm{U} 0126(20 \mu \mathrm{M})$ for $24 \mathrm{~h}$. The number of migrated cells was counted and normalized to the control. Values are expressed as mean \pm standard deviation. ERK, extracellular signal-regulated kinase; BaP, benzo(a)pyrene; p-ERK, phosphorylated ERK.

p-STAT3, Twist1 and STIM1, was also detected in Hep-G2 cells induced by $\mathrm{BaP}$, but $\mathrm{BaP}$ treatment did not have any notable effects on the expression of these proteins (data not shown).

\section{Discussion}

It has been reported that several key molecular events are implicated in BaP-induced hepato-carcinogenesis. Bolotina et al (35) demonstrated that BaP-dependent activation of transcript factors nuclear factor (NF)- $\mathrm{B}$ and activator protein 1 (AP-1) was associated with tumor promotion in hepatoma cell cultures. Cui et al (36) demonstrated that pregnane $\mathrm{X}$ receptor regulated the AhR/CYP1A1 pathway and protected liver cells from BaP-induced DNA damage. Marrone et al (37) reported that treatment of HepaRG cells with $\mathrm{BaP}$ resulted in specific changes in the expression of microRNAs compared with their non-carcinogenic analogues. Souza et al (38) demonstrated that $\mathrm{BaP}$ and its major metabolites deregulated metastatic markers via non-genotoxic and genotoxic mechanisms and activated the inflammatory pathway $(\mathrm{NF}-\kappa \mathrm{B}$ signaling and cytokine-cytokine receptor interaction) in Hep-G2 cells. BaP also induced strong repression of genes involved in cholesterol and fatty acid biosynthesis in Hep-G2 cells (38).
Previous studies have documented the association between BaP exposure and cancer cell invasion and metastasis. Ueng et al (39) reported that $\mathrm{BaP}$ treatment enhanced the invasive ability of lung cancer CL5 cells in vitro. Wang et al (30) indicated that BaP treatment may promote A549 lung cancer cell migration and invasion. Miller et al (40) reported that BaP treatment increased the invasion abilities of human breast cancer MDA-MB-231 cells. The present study observed that BaP treatment enhanced the abilities of migration and invasion in liver cancer Hep-G2 cells in vitro. The results of the present study are consistent with previous observations (16). Ba et al (16) observed that chronic BaP exposure was able to promote liver cancer cell migration and invasion in vivo and in vitro. Taken together, the results of the present study indicated that exposure to BaP had effects on liver cancer metastasis and progression.

Numerous studies have demonstrated that ERK signaling is involved in BaP-induced carcinogenesis. For example, Patten Hitt et al (41) demonstrated that BaP activated ERK, which was involved in cell proliferation, in colon adenocarcinoma HT29 cells (41). Wang et al (42) reported that BaP-induced cell cycle progression occurred via the ERK-induced checkpoint kinase 1 pathway activation in human lung cancer cells. Kometani et al (43) reported that the EGFR tyrosine kinase inhibitor reduced the cellular proliferation and the level of 
phosphorylation of ERK1/2, which is a downstream signal of the EGFR in BaP-treated A549 cells. The present study observed that $\mathrm{BaP}$ treatment increased the level of $\mathrm{p}$-ERK protein expression in Hep-G2 cells, and the ERK inhibitor, U0126, blocked BaP-induced Hep-G2 cell migration and invasion, which suggested that ERK activation may mediate BaP-induced migration and invasion in Hep-G2 cells. Two previous studies have demonstrated that elevated ERK activity is required for $\mathrm{BaP}-$ induced migration and invasion in human breast cancer MDA-MB-231 and MCF-7 cells $(29,44)$. Taken together, the results of the present study and previous studies suggested that ERK signaling served an important role in the migration and invasion of different types of cancer cells induced by BaP.

Vimentin, a type III intermediate filament protein, is expressed in mesenchymal cells. Vimentin is often used as a marker of liver cancer metastasis. Hu et al (45) reported that overexpression of vimentin was significantly associated with liver cancer metastasis. Wei et al (46) reported that silencing of glucose-regulated protein 78 enhanced liver cancer cell migration through regulation of vimentin. Wang et al (47) demonstrated that long non-coding RNA AOC4P suppressed liver cancer metastasis by enhancing vimentin degradation and inhibiting epithelial-mesenchymal transition. The results of a study undertaken by Dong et al (34) indicated that osteopontin promoted epithelial-mesenchymal transition of liver cancer cells through regulating vimentin. The present study observed that $\mathrm{BaP}$ treatment increased the expression of vimentin protein, which was attenuated by inhibition of ERK activity.

There are several limitations to the present study. To begin with, Hep-G2 cells were treated with $\mathrm{BaP}(2,4$ and $8 \mu \mathrm{M})$ for $48 \mathrm{~h}$, which may be different from long-term exposure to low concentrations of $\mathrm{BaP}$ for humans under normal living conditions. Furthermore, although the results of the present study demonstrated that $\mathrm{BaP}$ exposure increased the expression of p-ERK at times between 24 and $72 \mathrm{~h}$, while the effects at times between 0 and $24 \mathrm{~h}$ were not investigated and require investigation in future studies. Additionally, the ERK inhibitor was revealed to attenuate $\mathrm{BaP}$-induced vimentin protein expression. However, the underlying mechanisms regarding how p-ERK regulates vimentin protein expression were not fully addressed in the present study and should be a focus of future studies. Furthermore, the potential role of ERK in BaP-induced migration and invasion was only investigated at the cellular level. Further studies on this topic based on animal experiments and population should be performed to verify the results of the present study.

The Hep-G2 cell line was originally thought to be a hepatocellular carcinoma cell line, but was later revealed to derive from a hepatoblastoma (28), and is most frequently used to study the invasion and metastasis of liver cancer (48-52). In the present study, the Hep-G2 cell line was used to investigate the potential role of $\mathrm{p}$-ERK in BaP-induced invasion and migration of liver cancer cells. Although this cell line was reported to be misidentified as hepatocellular carcinoma cell, this issue is unlikely to affect the outcomes of the present study.

In summary, to the best of our knowledge, the present study was the first to demonstrate that $\mathrm{BaP}$ exposure promoted Hep-G2 cell migration and invasion by upregulating p-ERK protein expression. The present study, in part, enriched understanding of the mechanisms on the increased risk of liver cancer metastasis among people who are exposed to BaP.

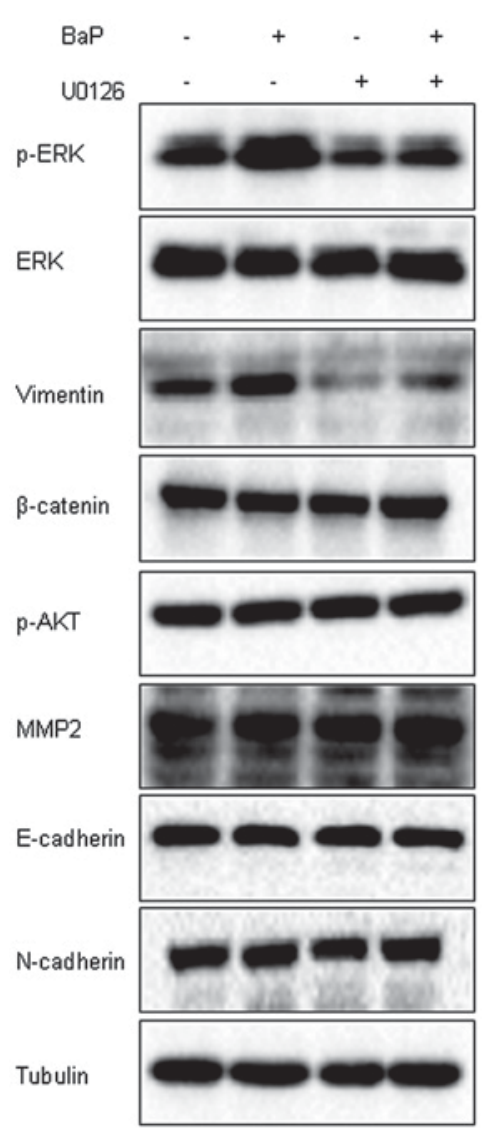

Figure 5. BaP-induced vimentin protein expression is modulated by ERK activation. Cells were seeded in $60-\mathrm{mm}$ plates and treated with $4 \mu \mathrm{M} \mathrm{BaP}$ or $20 \mu \mathrm{M} \mathrm{U} 0126$ for $48 \mathrm{~h}$. Western blot analysis was performed to analyze the level of protein expression. BaP, benzo(a)pyrene; ERK, extracellular signal-regulated kinase; p, phosphorylated; Akt, protein kinase B.

\section{Acknowledgements}

Not applicable.

\section{Funding}

The present study was supported by a grant from the National Natural Science Foundation of China (grant no. U1404815).

\section{Availability of data and materials}

The datasets generated/ analyzed during the present study are included in the published article.

\section{Authors' contributions}

YW contributed to study design, implementation, experiments, data analysis, and manuscript writing. YW, TP and LL contributed to western blot analysis. YW, LL, and HW contributed to the cell proliferation assay, wound healing assay and invasion assay. HY and DZ contributed to data analysis.

\section{Ethics approval and consent to participate}

Not applicable. 


\section{Consent for publication}

Not applicable.

\section{Competing interests}

All authors declare that they have no competing interests.

\section{References}

1. IARC Working Group on the Evaluation of Carcinogenic Risks to Humans: Some non-heterocyclic polycyclic aromatic hydrocarbons and some related exposures. IARC Monogr Eval Carcinog Risks Hum 92: 1-853, 2010

2. He XZ, Chen W, Liu ZY and Chapman RS: An epidemiological study of lung cancer in Xuan Wei County, China: Current progress. Case-control study on lung cancer and cooking fuel. Environ Health Perspect 94: 9-13, 1991.

3. Yoshimoto T, Inoue T, Iizuka H, Nishikawa H, Sakatani M, Ogura T, Hirao F and Yamamura Y: Differential induction of squamous cell carcinomas and adenocarcinomas in mouse lung by intratracheal instillation of benzo(a)pyrene and charcoal powder. Cancer Res 40: 4301-4307, 1980.

4. Senthilnathan P, Padmavathi R, Magesh V and Sakthisekaran D Chemotherapeutic efficacy of paclitaxel in combination with Withania somnifera on benzo(a)pyrene-induced experimenta lung cancer. Cancer Sci 97: 658-664, 2006.

5. Anderson KE, Kadlubar FF, Kulldorff M, Harnack L, Gross M, Lang NP, Barber C, Rothman N and Sinha R: Dietary intake of heterocyclic amines and benzo(a)pyrene: Associations with pancreatic cancer. Cancer Epidemiol Biomarkers Prev 14: 2261-2265, 2005.

6. Li D, Day RS, Bondy ML, Sinha R, Nguyen NT, Evans DB, Abbruzzese JL and Hassan MM: Dietary mutagen exposure and risk of pancreatic cancer. Cancer Epidemiol Biomarkers Prev 16: 655-661, 2007.

7. Ronco AL, De Stefani E, Correa P,Deneo-Pellegrini H, Boffetta P, Acosta G and Mendilaharsu M: Dietary benzo[a]pyrene, alcohol drinking, and risk of breast cancer: A case-control study in Uruguay. Asian Pac J Cancer Prev 12: 1463-1467, 2011.

8. Roe FJ and Waters MA: Induction of hepatoma in mice by carcinogens of the polycyclic hydrocarbon type. Nature 214 299-300, 1967

9. Vesselinovitch SD, Kyriazis AP, Mihailovich N and Rao KV: Conditions modifying development of tumors in mice at various sites by benzo(a)pyrene. Cancer Res 35: 2948-2953, 1975.

10. Su Y, Zhao B, Guo F, Bin Z, Yang Y, Liu S, Han Y, Niu J, Ke X, Wang $\mathrm{N}$, et al: Interaction of benzo[a]pyrene with other risk factors in hepatocellular carcinoma: A case-control study in Xiamen, China. Ann Epidemiol 24: 98-103, 2014.

11. Abe S, Nemoto $\mathrm{N}$ and Sasaki M: Sister-chromatid exchange induction by indirect mutagens/carcinogens, aryl hydrocarbon hydroxylase activity and benzo[alpha]pyrenemetabolismincultured human hepatoma cells. Mutat Res 109: 83-90, 1983.

12. Cherpillod P and Amstad PA: Benzo[a]pyrene-induced mutagenesis of p53 hot-spot codons 248 and 249 in human hepatocytes. Mol Carcinog 13: 15-20, 1995.

13. Park SY, Lee SM, Ye SK, Yoon SH, Chung MH and Choi J: Benzo[a]pyrene-induced DNA damage and p53 modulation in human hepatoma HepG2 cells for the identification of potential biomarkers for PAH monitoring and risk assessment. Toxicol Lett 167: 27-33, 2006.

14. Delgado ME, Haza AI, Arranz N, Garcia A and Morales P: Dietary polyphenols protect against $\mathrm{N}$-nitrosamines and benzo(a) pyrene-induced DNA damage (strand breaks and oxidized purines/pyrimidines) in HepG2 human hepatoma cells. Eur J Nutr 47: 479-490, 2008.

15. Tian M, Zhao B, Zhang J, Martin FL, Huang Q, Liu L and Shen H: Association of environmental benzo[a]pyrene exposure and DNA methylation alterations in hepatocellular carcinoma: A Chinese case-control study. Sci Total Environ 541: 1243-1252, 2016.

16. Ba Q, Li J, Huang C, Qiu H, Li J, Chu R, Zhang W, Xie D, Wu Y and Wang $\mathrm{H}$ : Effects of benzo[a]pyrene exposure on human hepatocellular carcinoma cell angiogenesis, metastasis, and NF- $\mathrm{B}$ signaling. Environ Health Perspect 123: 246-254, 2015.
17. Sun Y, Liu WZ, Liu T, Feng X, Yang N and Zhou HF: Signaling pathway of MAPK/ERK in cell proliferation, differentiation, migration, senescence and apoptosis. J Recept Signal Transduct Res 35: 600-604, 2015.

18. Osaki LH and Gama P: MAPKs and signal transduction in the control of gastrointestinal epithelial cell proliferation and differentiation. Int J Mol Sci 14: 10143-10161, 2013.

19. Li L, Zhao GD, Shi Z, Qi LL, Zhou LY and Fu ZX: The $\mathrm{Ras} / \mathrm{Raf} / \mathrm{MEK} / \mathrm{ERK}$ signaling pathway and its role in the occurrence and development of HCC. Oncol Lett 12: 3045-3050, 2016.

20. McCubrey JA, Steelman LS, Chappell WH, Abrams SL, Wong EW, Chang F, Lehmann B, Terrian DM, Milella M, Tafuri A, et al: Roles of the Raf/MEK/ERK pathway in cell growth, malignant transformation and drug resistance. Biochim Biophys Acta 1773: 1263-1284, 2007.

21. Yang S and Liu G: Targeting the Ras/Raf/MEK/ERK pathway in hepatocellular carcinoma. Oncol Lett 13: 1041-1047, 2017.

22. Mehdizadeh A, Somi MH, Darabi M and Jabbarpour-Bonyadi M: Extracellular signal-regulated kinase 1 and 2 in cancer therapy: A focus on hepatocellular carcinoma. Mol Biol Rep 43: 107-116, 2016.

23. Chen Y, Liu Q, Wu M, Li M, Ding H, Shan X, Liu J, Tao T, Ni R and Chen X: GAB2 promotes cell proliferation by activating the ERK signaling pathway in hepatocellular carcinoma. Tumour Biol 37: 11763-11773, 2016.

24. Ito Y, Sasaki Y, Horimoto M, Wada S, Tanaka Y, Kasahara A, Ueki T, Hirano T, Yamamoto H, Fujimoto J, et al: Activation of mitogen-activated protein kinases/extracellular signal-regulated kinases in human hepatocellular carcinoma. Hepatology 27: 951-958, 1998.

25. Schmitz KJ, Wohlschlaeger J, Lang H, Sotiropoulos GC, Malago M, Steveling K, Reis H, Cicinnati VR, Schmid KW and Baba HA: Activation of the ERK and AKT signalling pathway predicts poor prognosis in hepatocellular carcinoma and ERK activation in cancer tissue is associated with hepatitis $\mathrm{C}$ virus infection. J Hepatol 48: 83-90, 2008.

26. Jiang L, Yan Q, Fang S, Liu M, Li Y, Yuan YF, Li Y, Zhu Y, Qi J, Yang $\mathrm{X}$, et al: Calcium-binding protein 39 promotes hepatocellular carcinoma growth and metastasis by activating extracellular signal-regulated kinase signaling pathway. Hepatology 66: 1529-1545, 2017.

27. Dang Z, Shangguan J, Zhang C, Hu P, Ren Y, Lv Z, Xiang H and Wang X: Loss of protocadherin-17 (PCDH-17) promotes metastasis and invasion through hyperactivation of EGFR/MEK/ERK signaling pathway in hepatocellular carcinoma. Tumour Biol 37: 2527-2535, 2016

28. López-Terrada D, Cheung SW, Finegold MJ and Knowles BB: Hep G2 is a hepatoblastoma-derived cell line. Hum Pathol 40: $1512-1515,2009$

29. Guo J, Xu Y, Ji W, Song L, Dai C and Zhan L: Effects of exposure to benzo[a]pyrene on metastasis of breast cancer are mediated through ROS-ERK-MMP9 axis signaling. Toxicol Lett 234: 201-210, 2015.

30. Wang Y, Zhai W, Wang H, Xia X and Zhang C: Benzo(a)pyrene promotes A549 cell migration and invasion through up-regulating twist. Arch Toxicol 89: 451-458, 2015.

31. Wang Z, Shen M, Lu P, Li X, Zhu S and Yue S: NEDD9 may regulate hepatocellular carcinoma cell metastasis by promoting epithelial-mesenchymal-transition and stemness via repressing Smad7. Oncotarget 8: 1714-1724, 2017.

32. Wang C, Ruan P, Zhao Y, Li X, Wang J, Wu X, Liu T, Wang S, Hou J, Li W, et al: Spermidine/spermine N1-acetyltransferase regulates cell growth and metastasis via $\mathrm{AKT} / \beta$-catenin signaling pathways in hepatocellular and colorectal carcinoma cells. Oncotarget 8: 1092-1109, 2017

33. Ye Y, Long X, Zhang L, Chen J, Liu P, Li H, Wei F, Yu W, Ren X and Yu J: NTS/NTR1 co-expression enhances epithelial-to-mesenchymal transition and promotes tumor metastasis by activating the $\mathrm{Wnt} / \beta$-catenin signaling pathway in hepatocellular carcinoma. Oncotarget 7: 70303-70322, 2016

34. Dong Q, Zhu X, Dai C, Zhang X, Gao X, Wei J, Sheng Y, Zheng Y, Yu J, Xie L, et al: Osteopontin promotes epithelial-mesenchymal transition of hepatocellular carcinoma through regulating vimentin. Oncotarget 7: 12997-13012, 2016.

35. Bolotina NA, Gasparian AV, Dubovaja TK, Evteev VA and Kobliakov VA: Benzo[a]pyrene-dependent activation of transcription factors NF-kappaB and AP-1 related to tumor promotion in hepatoma cell cultures. Biochemistry (Mosc) 72: 552-557, 2007. 
36. Cui H, Gu X, Chen J, Xie Y, Ke S, Wu J, Golovko A, Morpurgo B, Yan C, Phillips TD, et al: Pregnane X receptor regulates the AhR/Cyp1A1 pathway and protects liver cells

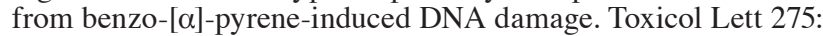
67-76, 2017.

37. Marrone AK, Tryndyak V, Beland FA and Pogribny IP: MicroRNA responses to the genotoxic carcinogens aflatoxin B1 and Benzo[a]pyrene in human HepaRG cells. Toxicol Sci 149 496-502, 2016.

38. Souza T, Jennen D, van Delft J, van Herwijnen M, Kyrtoupolos S and Kleinjans J: New insights into BaP-induced toxicity: Role of major metabolites in transcriptomics and contribution to hepatocarcinogenesis. Arch Toxicol 90: 1449-1458, 2016.

39. Ueng TH, Chang YL, Tsai YY, Su JL, Chan PK, Shih JY, Lee YC, Ma YC and Kuo ML: Potential roles of fibroblast growth factor-9 in the benzo(a)pyrene-induced invasion in vitro and the metastasis of human lung adenocarcinoma. Arch Toxicol 84: 651-660, 2010.

40. Miller ME, Holloway AC and Foster WG: Benzo-[a]-pyrene increases invasion in MDA-MB-231 breast cancer cells via increased COX-II expression and prostaglandin E2 (PGE2) output. Clin Exp Metastasis 22: 149-156, 2005.

41. Patten Hitt E, DeLong MJ and Merrill AH Jr: Benzo(a)pyrene activates extracellular signal-related and p38 mitogen-activated protein kinases in HT29 colon adenocarcinoma cells: Involvement in $\mathrm{NAD}(\mathrm{P}) \mathrm{H}$ :quinone reductase activity and cell proliferation. Toxicol Appl Pharmacol 183: 160-167, 2002.

42. Wang BY, Wu SY, Tang SC, Lai CH, Ou CC, Wu MF, Hsiao YM and Ko JL: Benzo[a]pyrene-induced cell cycle progression occurs via ERK-induced Chk1 pathway activation in human lung cancer cells. Mutat Res 773: 1-8, 2015.

43. Kometani T, Yoshino I, Miura N, Okazaki H, Ohba T, Takenaka T, Shoji F, Yano $\mathrm{T}$ and Maehara Y: Benzo[a]pyrene promotes proliferation of human lung cancer cells by accelerating the epidermal growth factor receptor signaling pathway. Cancer Lett 278: 27-33, 2009.

44. Castillo-SanchezR,Villegas-ComonfortS,Galindo-HernandezO, Gomez R and Salazar EP: Benzo-[a]-pyrene induces FAK activation and cell migration in MDA-MB-231 breast cancer cells. Cell Biol Toxicol 29: 303-319, 2013.
45. Hu L, Lau SH, Tzang CH, Wen JM, Wang W, Xie D, Huang M, Wang Y, Wu MC, Huang JF, et al: Association of Vimentin overexpression and hepatocellular carcinoma metastasis. Oncogene 23: 298-302, 2004

46. Wei PL, Kuo LJ, Wang W, Lin FY, Liu HH, How T, Ho YS, Huang MT, Wu CH and Chang YJ: Silencing of glucose-regulated protein 78 (GRP78) enhances cell migration through the upregulation of vimentin in hepatocellular carcinoma cells. Ann Surg Oncol 19 (Suppl 3): S572-S579, 2012.

47. Wang TH, Lin YS, Chen Y, Yeh CT, Huang YL, Hsieh TH, Shieh TM, Hsueh C and Chen TC: Long non-coding RNA AOC4P suppresses hepatocellular carcinoma metastasis by enhancing vimentin degradation and inhibiting epithelial-mesenchymal transition. Oncotarget 6: 23342-23357, 2015.

48. Xie X, Zhu H, Zhang J, Wang M, Zhu L, Guo Z, Shen W and Wang D: Solamargine inhibits the migration and invasion of HepG2 cells by blocking epithelial-to-mesenchymal transition. Oncol Lett 14: 447-452, 2017.

49. Chen C, Xue Y, Zhang D, Xu W, Xu H, Yao H, Pei D and Gu Y: Short hairpin RNA silencing of TGF- $\beta$ RII and FZD-7 synergistically suppresses proliferation and metastasis of hepatocellular carcinoma cells. Oncol Lett 11: 2039-2046, 2016.

50. He S, Lin J, Yu S and Sun S: Upregulation of PREX2 promotes the proliferation and migration of hepatocellular carcinoma cells via PTEN-AKT signaling. Oncol Lett 11: 2223-2228, 2016.

51. Liu Z, Wang J, Mao Y, Zou B and Fan X: MicroRNA-101 suppresses migration and invasion via targeting vascular endothelial growth factor- $\mathrm{C}$ in hepatocellular carcinoma cells. Oncol Lett 11: 433-438, 2016.

52. Zhao X, Yang W, Pei F, Ma W and Wang Y: Downregulation of matrix metalloproteinases contributes to the inhibition of cell migration and invasion in HepG2 cells by sodium valproate. Oncol Lett 10: 531-535, 2015.

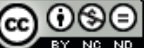

This work is licensed under a Creative Commons Attribution-NonCommercial-NoDerivatives 4.0 International (CC BY-NC-ND 4.0) License. 